\title{
TWO NEW RECORDS OF LONG-EARED MYOTIS IN SASKATCHEWAN
}

\section{by William J. Maher, University of Saskatchewan, Saskatoon}

On June 11, 1969 Brian E. Felske found a bat in a crevice between two boulders on a south-facing slope of the South Saskatchewan River Valley on the Matador Field Station, near Beechy, Saskatchewan. The precise locality was Section 14, Township 20, Range 13 , west of the third meridian. The specimen was a male with measurements: TL 81, T 39, HF 10, Ear 17, Tragus $11 \mathrm{~mm}$. , and is specimen No. 2713 of the University of Saskatchewan vertebrate collection. It has been identified by R. Peterson, ROM, as a Long - eared Myotis (Myotis evotis).

Southwestern Saskatchewan is the northeast corner of the range of this species. Although it was recorded 25 years ago in Rumsey, Alberta (Anderson, 1947) it was not identified in this province until 1960 (Nero, 1960). There is one subsequent published record of the species in Saskatchewan (Nero, 1963) and a third specimen, now in the Saskatchewan Museum of Natural History (R. Long, in Litt.), was taken at Big Muddy Lake on June $5,1965$.

The four records of this bat are all in the southwestern part of the province, the specimen reported here being the most northerly. All these records are from May and June, and it appears that this species may be a regu- lar, if uncommon, summer visitor to the province. We could use more records of this bat.

The long-eared Myotis inhabits thinly forested to semi-desert areas. It is reported to roost in caves at night between foraging trips; but it roosts in day time in small groups in buildings and trees (Hall and Kelson, 1959; Barbour and Davis, 1969). The specimen reported here, as well as one previous one from Saskatchewan (Nero, 1963) were found under rocks, and this may be, in fact, the typical day time roosting site for the species.

Naturalists should be aware that this and two other small brown Myotis: Keen's Myotis (M. keeni) and Small-footed Myotis (M. subulatus), are known from only a couple of records from the province, and it would be useful to have more specimens of small brown bats preserved and identified (see Beck, 1958, and Nero, 1963).

\section{LITERATURE CITED}

Anderson, R. M. 1947. Catalogue of Canadian recent mammals. Bull. Nat. Mus. Canada, 102: v +238 pp.

Beck, W. H. 1958. A guide to Saskatchewan mammals. Sask. Nat. Hist. Soc., Special Publ. No. 1, 1-52 pp.

Hall, E. R., and K. R Kelson, 1959. The mammals of North America. Vol. I. Ronald Press. $\mathrm{xxx}+625 \mathrm{pp}$.

Nero, R. W. 1960. Long-eared Myotis found in Saskatchewan. Blue Jay, $18: 181$.

Nfro, R. W 1963. A second record of the Long-eared Myotis bat. Blue Jay, 21:119.

\section{HOARY BAT PARTURITION DATE AND CAPTIVITY RECORD}

\section{by William J. Maher, University of Saskatchewan, Saskatoon}

Very little is known about the Hoary Bat (Lasiurus cinereus Beauvois), the largest North American bat. This is in part because it is solitary, seldom enters buildings or caves and usually starts flying later in the evening than other bat species. Because of the scarcity of information on the hoary bat,
I thought that this record, based on one bat kept in captivity, would be of interest.

A female hoary bat was found hanging in a maple tree in a cemetery near Floral, Saskatchewan on June 24, 1969 by D. W. T. Whitfield and G. Michalenko. She gave birth to two young on 


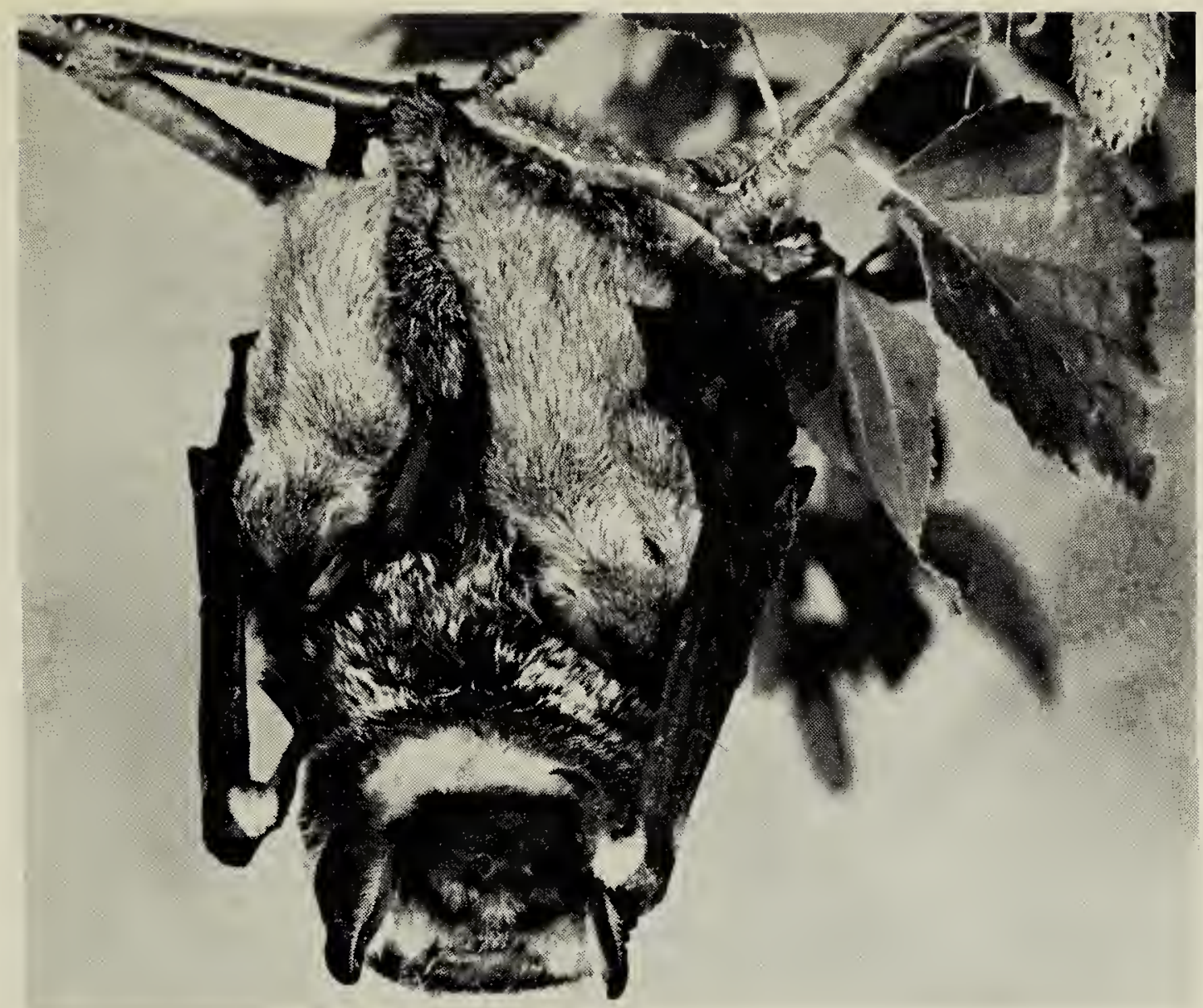

Hoary Bat, June 28, 1969

Photo by John Waddington

June 25 or 26 in the animal room in the Department of Biology, University of Saskatchewan in Saskatoon. One young survived for about two weeks and died on July 11. The second young lived for about a month longer. The date of its death was not recorded. The female lived until December 28 and died after about six months in captivity.

The bats were kept in a 15-gallon aquarium provided with a water dish and a branch to hang on. The female refused to eat newly born mice and only accepted Tenebrio larvae and pupae with the pupae being definitely preferred. She was hand fed up to 30 Tenebrio a day; she never learned to pick up any food. Every two or three days some larvae were dipped in cod liver oil before they were fed to her.

The litter size of the species is always two, and parturition occurs from the middle of May to early July (Barbour and Davis, Bats of America, Univ. Press of Kentucky, 1969). The one previous record of parturition that I have found from Saskatchewan was on June 24 (Nero, "Hoary bat parturi- tion date". Blue Jay, 16:130-131, 1958).

The female is thought to leave the young hanging on a twig while she forages; but Poole (in Barbour and Davis, 1969) shot one bat carrying two young less than a week old. We found that the two young remained on the female until July 7 when they were 12 days old. This suggests the possibility that the young may be carried by the female until they are more than a week old. Feeding by regurgitation was first observed on July 4 when the young were about nine days old. The older surviving young was eating Tenebrio larvae out of hand before it died.

This seems to be the longest record to date of a hoary bat's surviving in captivity. Barbour and Davis (1969) note one which was kept for two weeks and fed on dead mice, while Peterson (The Mammals of Eastern Canada. Oxford Univ. Press, Toronto, 1966) records a male which survived for six weeks on mealworms and other insects. The specimen reported by Nero (1958) survived for less than one week. 